\title{
Molecular Characterization of Glucose-6-Phosphate Dehydrogenase Deficiency in a University Community in Malaysia
}

\author{
Ahmed M Sulaiman ${ }^{1}$, Sultan AM Saghir ${ }^{2 \star}$, Faisal M Al-Hassan ${ }^{1}$, Narazah M \\ Yusoff ${ }^{1}$ and Abdel-Hamid A Zaki ${ }^{1}$ \\ ${ }^{1}$ Advanced Medical and Dental Institute (AMDI), Universiti Sains Malaysia (USM), No 1-8 (Lot 8), Persiaran Seksyen 4/1, Bandar Putra \\ Bertam, 13200 Kepala Batas. Pulau Pinang, ${ }^{2}$ School of Pharmaceutical Sciences, Pharmacology Department, Penang, Malaysia
}

*For correspondence: Email: sultan_a1976@yahoo.com; Tel: 0060142415953

\begin{abstract}
Purpose: To determine the prevalence of glucose-6-phosphate dehydrogenase (G6PD) deficiency among staff and students of a university community in Malaysia as well as to identify molecular genetics by determination of G6PD mutations.

Methods: Cross-sectional and experimental studies were carried out on the staff and students of Advanced Medical and Dental Institute (AMDI) of Universiti Sains Malaysia (USM) from July 2009 to April 2010. Venous blood samples were collected from 87 individuals (45 males and 42 females), all of whom gave informed consent. Full blood count, reticulocyte count, screening test and quantitative determination of G6PD were performed. The deficient subjects were confirmed by standard PCR restriction enzyme. DNA samples from these subjects were analyzed for certain known G6PD mutations by digesting them with appropriate restriction enzymes.

Results: Out of the 87 subjects (80 were Malay, 2 were Chinese, 1 was Indian and 4 were others). The total prevalence of G6PD deficiency among the subjects was $4.59 \%$ (4/87), all of whom were Malay males. One of the deficient subjects had G6PD Viangchan, while the other three were G6PD Mahidol (487 G>A).

Conclusion: The finding of this study demonstrate that the most common mutation among AMDI staff and students is Mahidol (487G>A), followed by mutation Viangchan (871G>A).
\end{abstract}

Keywords: Glucose-6-Phosphate Dehydrogenase, Mahidol, Viangchan, Haemolytic anaemia

Tropical Journal of Pharmaceutical Research is indexed by Science Citation Index (SciSearch), Scopus, International Pharmaceutical Abstract, Chemical Abstracts, Embase, Index Copernicus, EBSCO, African Index Medicus, JournalSeek, Journal Citation Reports/Science Edition, Directory of Open Access Journals (DOAJ), African Journal Online, Bioline International, Open-J-Gate and Pharmacy Abstracts

\section{INTRODUCTION}

G6PD deficiency is the most common human enzyme defect, being present in more than 400 million people globally. This condition occurs most frequently in certain parts of Africa, Asia, and the Mediterranean region. It affects about one-tenth of African-American males in the United States. The worldwide distribution of this disorder is remarkably similar to that of malaria
[1]. G6PD enzyme protects RBCs from harmful by-products that are produced as a result of taking certain medications or when the body is fighting an infection.

In people with G6PD deficiency, either the RBCs do not make enough G6PD or what is produced cannot properly function. Without enough G6PD to protect them, RBCs can be damaged or destroyed. Haemolytic anaemia occurs when the bone marrow cannot 
compensate for this destruction by increasing its production of RBCs. G6PD is a housekeeping enzyme that plays an essential role in reducing nicotinamide adenine dinucleotide phosphate (NADP) to NADPH. In a reaction catalyzed by G6PD, electrons generated by the conversion of glucose-6phosphate (G6P) to 6-phosphogluconate (6PG) are transferred to NADP [2].

The main problem in G6PD-deficient individuals occurs immediately after birth. Neonatal jaundice and chronic haemolytic anaemia are caused by this inherited disorder. Although most affected individuals are asymptomatic, the exposures to oxidative stressors such as certain drugs or infections are the cause of morbidity from G6PD deficiency [3]. G6PD deficiency is a genetic disorder that occurs most frequently in males. It is an X-linked genetic disorder. About 140 mutations have been described, in which most are single base changes, leading to amino acid substitutions. However, the majority of the mutations cause red cell enzyme deficiency due to the decrease of the enzyme stability. The most important clinical manifestation of G6PD deficiency is severe neonatal hyperbilirubinemia. A neonatal screening program using fluorescent spot test has been installed in all public hospitals since 1980 [4].

In this study, our attention was focused on the determination of the prevalence of G6PD deficiency and the predominant mutation (Viangchan or Mahidol) among the staff and students of Advanced Medical and Dental Institute (AMDI) of Universiti Sains Malaysia (USM). Also it aimed to check out the personalized health care and ultimately avoid haemolytic attacks.

\section{EXPERIMENTAL}

Blood samples $(5 \mathrm{~mL})$ were collected from the cubital vein of the forearm of 87 participants who had given informed consent.

Blood samples were processed and subjected to full blood count (FBC) analysis using blood counter Sysmex KX-21 for screening of hemoglobin $(\mathrm{Hb})$, white blood cells (WBC's), red blood cells (RBC's), platelets (PLT's), hematocrite (HCT), mean cell volume (MCV), mean cell hemoglobin $(\mathrm{MCH})$, mean cell hemoglobin concentration (MCHC) and cells morphology. Manual reticulocyte count (Retic`s) was carried out using new methylene blue stain for detection of non-nucleated immature red cell containing residual RNA. The G6PD deficiency screening was investigated using fluorescent spot test and G6PD assay activity using Selectra-E (All Eights (M) SDN $\mathrm{BHD})$ to detect and investigate the deficient samples.

G6PD enzyme activity was calculated as haemoglobin $(\mathrm{Hb}) \mathrm{U} / \mathrm{g}$ by Eq 1 .

G6PD $\mathrm{mU} / \mathrm{g} \mathrm{Hb}=\mathrm{mU}$. RBC per $\mathrm{ml} \times 100 / \mathrm{Hb}$ $(g / d l)$

where 100 = factor to convert activity to 100 $\mathrm{ml}$, and $\mathrm{Hb}(\mathrm{g} / \mathrm{dl})=$ haemoglobin concentration determined for each sample.

This study was approved by the Ethics and Research Committee of AMDI, USM (USM / Human Ethics Approval /2009/ (21) (134)). The participants signed a consent form before blood sample collection and Helsinki Declaration guidelines were followed in this study (11).

The G6PD deficient samples were analyzed by polymerase chain reaction (PCR) using Thermal Cycler (BioRad MyCycler, USA) and restriction enzyme digest to determine mutation variants.

PCR was used to amplify specific regions of the extracted DNA. PCR was carried out on 4 deficient samples and 1 normal subject as a control and it was performed on a volume of 25 $\mu \mathrm{l}$ (including $12.5 \mu \mathrm{l}$ of GoTaq green master mix). To determine G6PD Viangchan (871G $>A$ ) mutation, a mutagenic primer pair, 871F (5TGGCTITCTCTCAGGTCTAG-3) and 871R (5GTCGTCCAGGTACCCTITGGGG-3), were used. The primers were used to target exon 9 in PCR.

PCR amplification was performed on the DNA thermal cycler as follows: 1 cycle at $95{ }^{\circ} \mathrm{C}$ for 5 $\mathrm{min}$, then 35 cycles at $95{ }^{\circ} \mathrm{C}$ for $1 \mathrm{~min}, 56{ }^{\circ} \mathrm{C}$ for $1 \mathrm{~min}, 72{ }^{\circ} \mathrm{C}$ for $1 \mathrm{~min}$, and final extension at 72 ${ }^{\circ} \mathrm{C}$ for $10 \mathrm{~min}$. Ten microlitres of PCR product was digested with $20 \mu \mathrm{l}(10 \mathrm{U})$ of Xbal restriction enzyme for $2 \mathrm{~h}$, and then resolved on $3 \%$ agarose gel containing ethidium bromide as previously described [7]. A mutagenic primer pair, 487F (5-GCGTCTGAATGATGCAGCT CTGAT-3) and 487R (5-CTCCACGATGATCG GTTCAAGC-3), were used for G6PD Mahido (487 G>A) mutation assay. The primers were used to target exon 6 . The PCR reaction was the same as described in the previous test except the restriction enzyme used was HindlII. 


\section{Statistical analysis}

The data obtained were analyzed using Statistical Package for Social Sciences (SPSS) version 17. Using Independent samples $t$-test, differences between data for normal and G6PD-deficient subjects were considered significant at $p<0.05$.

\section{RESULTS}

Out of a total of 87 subjects ( 45 males and 42 females), 80 were Malay, 2 were Chinese, 1 was Indian and 4 were other ethnic groups. The prevalence of G6PD-deficient individuals among the subjects was $4.6 \%$. The ethnic group of all deficient subjects was Malay and they were all males. Out of the 87 subjects, there were four G6PD-deficient subjects, representing $4.6 \%(4 / 87)$ of all samples and $8.9 \%(4 / 45)$ of male subjects.

Table 1 shows the blood count parameters WBC, RBC, Hb, PLT, and Ret - for the four G6PD-deficient subjects. All the blood count parameters in the four G6PD-deficient's subjects were within normal ranges.

G6PD activity results are listed in Table 2 . The highest value among G6PD-deficient subjects was $3.38 \mathrm{U} / \mathrm{g} \mathrm{Hb}$ while the lowest was $2.92 \mathrm{U} / \mathrm{g}$ $\mathrm{Hb}$. Table 3 shows the $p$-values for the blood parameters and G6PD activity. The difference between the normal and G6PD-deficient subjects were not significant except for G6PD enzyme activity $(p<0.001)$.

Table 1: Blood count parameters of the four G6PD-deficient subjects

\begin{tabular}{lccccc}
\hline Subject & $\begin{array}{c}\text { WBC } \\
(/ \mu \mathrm{L})\end{array}$ & $\begin{array}{c}\mathbf{R B C} \\
(/ \mu \mathrm{LL})\end{array}$ & $\begin{array}{c}\mathbf{H b} \\
(\mathbf{g} / \mathbf{d L}\end{array}$ & $\begin{array}{c}\text { PLT } \\
(/ \mu \mathrm{L})\end{array}$ & $\begin{array}{c}\text { Retic's } \\
\%\end{array}$ \\
\hline 1 & $8.8 \times 10^{3}$ & $4.95 \times 10^{6}$ & 14.3 & $204 \times 10^{3}$ & 0.7 \\
2 & $3.7 \times 10^{3}$ & $5.26 \times 10^{6}$ & 14.3 & $331 \times 10^{3}$ & 1.2 \\
3 & $5.6 \times 10^{3}$ & $5.36 \times 10^{6}$ & 15.8 & $209 \times 10^{3}$ & 1.0 \\
4 & $8.7 \times 10^{3}$ & $5.24 \times 10^{6}$ & 15.1 & $267 \times 10^{3}$ & 1.1 \\
\hline
\end{tabular}

Table 2: G6PD activity of the subjects

\begin{tabular}{lcc}
\hline Subject type & $\begin{array}{c}\text { Number of } \\
\text { subjects }\end{array}$ & $\begin{array}{c}\text { G6PD enzyme activity U/g Hb } \\
\text { (mean } \pm \text { SD) }\end{array}$ \\
\hline All subjects & 87 & $8.75 \pm 1.82$ \\
Normal subjects & 83 & $9.02 \pm 1.36$ \\
G6PD-deficient subjects & 4 & $3.19 \pm 0.19$ \\
\hline
\end{tabular}

Table 3: Blood parameters and G6PD and their corresponding $p$-values* (values in parenthesis denote standard deviation)

\begin{tabular}{|c|c|c|c|}
\hline Parameter & Normal subjects & G6PD-deficient subjects & $P$-value \\
\hline $\mathrm{RBC} / \mu \mathrm{l} \times 10^{6}$ & $5.01(0.57)$ & $5.20(0.18)$ & 0.12 \\
\hline $\mathrm{HGB}(\mathrm{g} / \mathrm{dL})$ & $13.65(1.69)$ & $14.88(0.72)$ & 0.15 \\
\hline HCT (\%) & $42.29(4.64)$ & $38.05(16.12)$ & 0.63 \\
\hline $\operatorname{MCV}(f L)$ & $84.67(5.92)$ & $87.53(2.82)$ & 0.34 \\
\hline $\mathrm{MCH}(p g)$ & $27.36(2.58)$ & $28.60(0.98)$ & 0.34 \\
\hline $\mathrm{MCHC}(\mathrm{g} / \mathrm{dL})$ & $32.25(1.24)$ & $32.68(0.49)$ & 0.50 \\
\hline PLT $\times 10^{3}$ & $289.20(60.30)$ & $252.75(59.49)$ & 0.24 \\
\hline $\begin{array}{l}\text { G6PD activity (U/g Hb) } \\
\text { Ret }(\%)\end{array}$ & $\begin{array}{l}9.02(1.36) \\
1.24(0.36)\end{array}$ & $\begin{array}{l}3.19(0.19) \\
1.00(0.22)\end{array}$ & $\begin{array}{c}<0.001 \\
0.12\end{array}$ \\
\hline
\end{tabular}

\section{First and second PCR product of exon 6}

One out of 4 deficient subjects showed G6PD Viangchan mutation at nt $(871 \mathrm{G} \rightarrow \mathrm{A})$ while the rest of the three samples were investigated for further mutation abnormality at exon 6 . The result of the first PCR product at exon 6 of the three subjects showed 3 identical bands (Figure 1).

The second amplification process, PCRrestriction enzyme and digested PCR product at exon 6 using restriction enzyme Hindll illustrates 
that all the three deficient subjects were carrying Mahidol mutation (Figure 2).

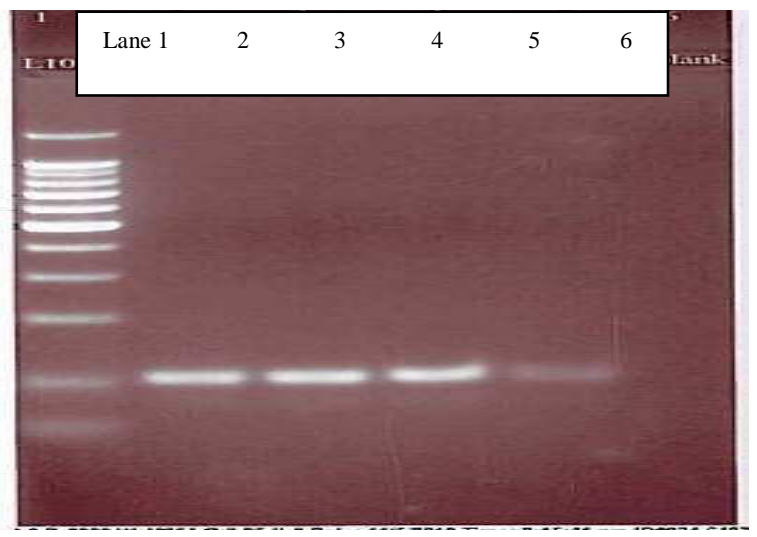

Figure 1: First PCR products of exon 6; agarose gel electrophoresis $(3 \%)$ of first PCR products of exon 6. Note: Lane 1 = Ladder DNA (100bp), Lanes 2, 3 and 4 $=P C R$ products for the three subjects, Lane $5=$ normal positive control and Lane 6: free nuclease water.

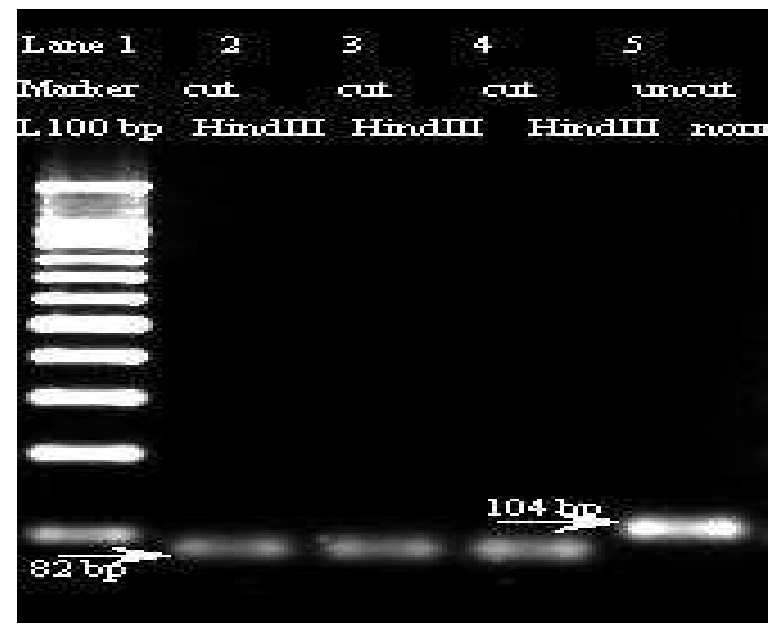

Figure 2: PCR products digest with Hindll restriction enzyme for G6PD Mahidol; agarose gel electrophoresis.

Note: Lane 1 = Ladder DNA (100 bp) = Lane 2, 3, 4 subjects' samples show cut with restriction enzyme HindIII at 82pb band which corresponds to Mahidol mutation $(487 G \rightarrow A)$, Lane $5=$ positive normal control (104bp).

\section{First and second PCR product at exon 9}

The result of first PCR product at exon 9 of the four deficient subjects showed 4 bands, indicating a successful amplification process (Figure 3). The second amplification process, PCR restriction enzyme of the four deficient subjects, was digested using restriction enzyme $X b a l$. Figure 4 illustrates the mutation of G6PD Viangchan $(871 \mathrm{G} \rightarrow \mathrm{A})$ in Lane 5 .

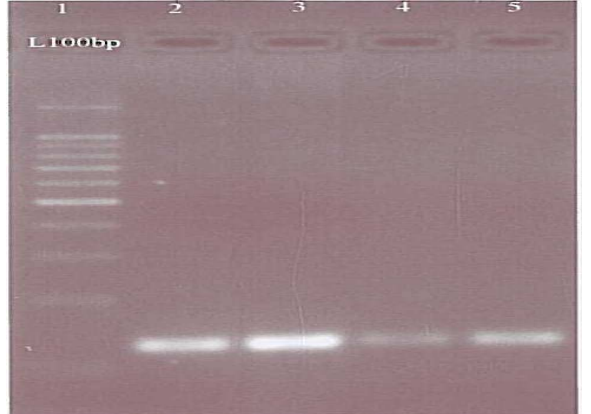

Figure 3: First PCR product at exon 9; agarose gel electrophoresis (3\%) shows first PCR product at exon 9 of the 4 subjects.

Note: Lane $1=$ Ladder DNA (100bp), Lanes $2-5=$ $\overline{P C R}$ product of the four subjects. The second amplification PCR process was carried out after the first amplification product, giving acceptable results

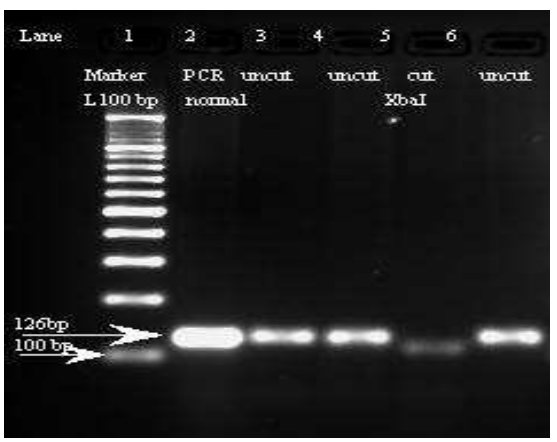

Figure 4: PCR products' digest with Xbal restriction enzyme for G6PD Viangchan.

Note: PCR was performed on genomic DNA for the four deficient subjects. All the G6PD-deficient subjects in this study had a normal full blood count and reticulocyte count, which indicates that they didn't have features of haemolyic episodes.

\section{DISCUSSION}

The findings of the present study are in agreement with those of previous studies [6,7]. In this study, the majorty of ethnic groups (male and female) were Malay. The results indicate a higher prevalence of G6PD among males than females. A similar observation was reported in Thailand by Nuchprayoon et al [8] who found that the deficiency in males and females was 11.1 and $5.8 \%$. Furthermore, in previous studies on Malay and Chinese neonates with G6PD deficiency in Malaysia, it appeared that the majority of the male G6PD-deficient neonates exhibited severe enzyme deficiency [7,9]. G6PD deficiency was found to be more prevalent among Malay and Malaysian Chinese ethnic groups and less among Indians [4,10].

The mean G6PD activity of 3.19 found in the present study is below the normal range $(6.97$ to 
$20.5 \mathrm{U} / \mathrm{g} \mathrm{Hb}$ ) indicated by the manufacturer of the test kit used (Randox Kits).

Standard PCR and restriction enzyme analyses were carried out to determine the molecular genetic mutations of the deficient subjects. The extracted genomic DNA was amplified by using reverse and forward primers designed to be targeted at exon 6 of the G6PD gene for Mahidol mutation and at exon 9 of the G6PD gene for Viangchan mutation. Therefore, exons 6 and 9 can be deemed as point mutations and the mutations would be expected to be found in these sites. One G6PD Viangchan mutation and three G6PD Mahidol mutations were found in the four deficient samples, and all of these mutations are located in southeast Asia region. The G6PD Viangchan mutation found in this study are in subjects of Malay ethnic stock. This gives some support to the finding of Wang et al, [11] who observed this mutation in Orang Asli (aboriginal Malaysians) race. This means that the mutation is common in Malaysia. In this study, $75 \%$ of the deficient subjects (3 out of four subjects) had a Mahidol mutation and all of them were Malays. The integration and closeness of people of these two countries may, amongst other factors, explain the presence of high levels of G6PD in Malaysia. Four of the G6PD-deficient subjects didn't have haemolytic anaemia and only one of them discovered for the first time that he has G6PD deficiency.

\section{CONCLUSION}

This study demonstrated that, the prevalence of G6PD deficiency among the students and staff of Malaysian descent is relatively high. In addition, this study reveals only two mutations Viangchan and Mahidol. It is recommended that early screening for G6PD deficiency should be carried out and a comprehensive investigation using large sample size and more than 4 mutations should be undertaken to reflect the full picture of the prevalence of G6PD in Malaysia.

\section{ACKNOWLEDGMENT}

The authors are grateful to Advanced Medical and Dental Institute staff and students for their cooperation and to Universiti Sains Malaysia for funding this research.

\section{COMPETING INTEREST}

The authors declare that they have no conflict of interest.

\section{REFERENCES}

1- Cappellini MD, Fiorelli G. Glucose-6-phosphate dehydrogenase deficiency. Lancet 2008; 371: 6474.

2- Mason PJ, Bautista JM, Gilsanz F. G6PD deficiency: the genotype-phenotype association. Blood Review 2007; 21: 267-283.

3- Nkhoma ET, Poole C, Vannappagari V, Hall SA, Beutler $E$. The global prevalence of glucose-6-phosphate dehydrogenase deficiency: Asystematic review and meta-analysis. Blood Cells Mol Dis. 2009; 42: 267278.

4- Ainoon O Alawiyah A, Yu1 YH, Cheong SK, Hamidah $\mathrm{NH}$, Boo NY, Zaleha M. Semiquantitative screening test for G6PD deficiency detects severe deficiency but misses a substantial proportion of partially-deficient females. Southeast Asian. 2003; 34: 405-414.

5- Williams JR. The Physician's Role in the Protection of Human Research Subjects. Sci Eng Ethics 2006; 12: 5-12.

6- Normah J, Choo KE, Oppenheimer SJ, Selamah G. Glucose-6-phosphate dehydrogenase enzyme activity in normal, hemizygote and heterozygote Kelantanese Malays. J Paediatr Child Health 1991; 27: 37-69.

7- Boo NY, Ainoon O, Zainal Arif ZA, Cheong SK, Haliza MS. Enzyme activity of glucose-6-phosphate dehydrogenase-deficient Malaysian neonates during the first 10 days of life. $J$ Paediatr Child Health. 1995; 31: 44-46.

8- Nuchprayoon I, Sanpavat S, Nuchprayoon S. Glucose6-Phosphate Dehydrogenase (G6PD) Mutations in Thailand: G6PD Viangchan $(871 G>A)$ Is the Most Common Deficiency Variant in the Thai Population. Human Muta. 2002; 481: 322-327.

9- Ainoon O, Joyce J, Boo NY, Cheong SK, Zainal ZA, Hamidah NH. Glucose-6-phosphate dehydrogenase (G6PD) variants in Malaysian Chinese. Hum Muta. 1999; 14: 352-355.

10- Ainoon O, Yu YH, Muhriz A, Boo NY, Cheong SK, Hamidah NH. Glucose-6-Phosphate Dehydrogenase (G6PD) Variants in Malaysian Malays. Human muta. 2002; 21: 1-9.

11- Wang J, Luo E, Hirai M, Arai M, Abdul Manan A, Isa Z, Hidayah N, Matsuoka H. Nine Different Glucose-6phosphate Dehydrogenase (G6PD) Variants in a Malaysian Population with Malay, Chinese, Indian and Orang Asli (Aboriginal Malaysian) Backgrounds. Acta Medica Okayma. 2008; 62: 327-332. 